\title{
Mechanization of milk production in the rotary milking parlor with loose cubicle technology for cow keeping
}

\author{
M.R. Kudrin, A.L. Shklyaev*, K.L. Shklyaev, I.A. Deryushev, and A.V. Kostin \\ FSBEI of HE Izhevsk SAA, Izhevsk, Russia
}

\begin{abstract}
The research was carried out in "Udmurtia" agricultural production co-operative (collective farm) of the Vavozhsky district of the Udmurt Republic". A complex for keeping 1200 cows with loose cubicle technology for cow keeping with milking in the milking parlor using the rotary milking equipment was built on the farm for the first time in the Udmurt Republic. In the course of the study, technological operations during keeping, feeding, milking cows at the rotary milking unit were studied; the timing of the cow milking process and the sequence of operations were carried out. Based on the research results, specific recommendations were given to the farm.
\end{abstract}

\section{Introduction}

In the modern world, the production technology is becoming a decisive factor in the growth of the economic potential of all animal husbandry branches, a profitable direction and object for the investment of capital and resources, an instrument of competition. The technology determines the level of intensity and efficiency of production, its environmental safety, product quality, biological and nutritional value of food products [1-6].

Modern dairy farming is developing mainly due to the intensification of production resources, where the main place is given to the process of intensive milk production in terms of industrial technology. Acceleration of the development rate and an increase in the efficiency of dairy cattle breeding is achieved by genetic improvement of livestock, an increase in the level and improvement in the quality of cow feeding, optimization of paratypical factors [7-12].

\section{Materials and methods}

The research was carried out in "Udmurtia" agricultural production co-operative (collective farm) of the Vavozhsky district of the Udmurt Republic".

The aim of the study was to study the technological operations during cow milking in the milking parlor on the rotary milking unit with loose cubicle keeping technology in

\footnotetext{
* Corresponding author: 79511917462@yandex.ru
} 
"Udmurtia" agricultural production co-operative (collective farm) of the Vavozhsky district of the Udmurt Republic.

In accordance with the set goal, the following tasks have been identified:

- to study the technological operations when keeping, feeding, milking cows at the rotary milking unit;

- to conduct the timing of the cow milking process and the sequence of operations.

The object of research was the livestock buildings, in which dairy cows of the Russian Black Pied breed were kept using loose cubicle keeping technology with milking in the milking parlor.

To carry out the research, the timing of individual technological operations during cow milking was carried out. Timing was carried out using a stopwatch in various physiological groups of cows. A complex for keeping 1200 cows with loose cubicle technology for cow keeping with milking in the milking parlor using the rotary milking equipment was built on the farm for the first time in the Udmurt Republic. The complex has two rooms for 600 cows each for cow keeping.

The cows are housed in four sections with 150 cows each. Currently, the animals are divided into sections according to the following principle:

Group 1 - production group - cows two months before launch;

Group 2 - milk yield increase - cows from the sixth day after calving and up to two months;

Group 3 - the main group - inseminated cows not tested for pregnancy (fresh cows);

Group 4 - mastitic cows.

The workload for one milking machine operator in the brigade will be 150 cows (1200: $8=150)$ after the complex is completely filled.

The floor in the cubicles where the cows rest is made of rubber mats, and in the sections where the animals move - concrete [13]. Bedding material is not used in the cubicles where animals rest, therefore the animals are dirty. It should be noted that in the cubicles where the animals rest, the sizes correspond to the sizes of the cows on the farm and amount to: cubicle length $-2.60 \mathrm{~m}$, cubicle width $-1.30 \mathrm{~m}$. Cows lie freely in the cubicles, mainly in the cow's resting position - bending the front limbs and stretching the hind limbs [14]. The height of the cubicle divider is $2.00 \mathrm{~m}$. The slope of the floor towards the manure channel is $2.0 \%$ (the norm is $1.5-2.0 \%$ ). The animals are fed from the manger, the width of which is $1.0 \mathrm{~m}$ on both sides. The width of the feed way is only $3.90 \mathrm{~m}$, so the width of the process way is $1.90 \mathrm{~m}(3.90 \mathrm{~m}-2.0 \mathrm{~m})$, which is enough for the feeder to pass through when dispensing feed. Feed is dispensed twice a day by a mixing feeder.

During the day, the cattlemen push feed to the animals 5-6 times per shift using a specially developed technique converted from a conventional single-axle tractor with a blade. This allows the cows to eat feed evenly from the manger and do not bother each other due to lack of feed on the manger. Feed is dispensed during the working day as the feed is consumed from $7.00 \mathrm{am}$ to $5.00 \mathrm{pm}$. The composition of the feed mixture includes the following feed: corn silage with ears $21 \mathrm{~kg}+$ straw $1.0 \mathrm{~kg}+$ haylage of perennial grasses $12.0 \mathrm{~kg}$ + green mass $1.0 \mathrm{~kg}+13.0$ of concentrates. The composition of concentrated feed includes: soybean $1.3 \mathrm{~kg}+$ rapeseed meal $2.0 \mathrm{~kg}+$ barley $4.0 \mathrm{~kg}+4.5 \mathrm{corn}+$ peas $800 \mathrm{~g}$. The cutting length of feed is from 5.0 to $7.0 \mathrm{~cm}$ depending on the type of feed (crop). Thus, the length of hay cutting is $7.0 \mathrm{~cm}$, corn for silage with ears $-1.5 \mathrm{~cm}$, green mass from perennial crops - 3.0-5.0 cm. It should be noted that the cutting length of the components is in the range of $2.0 \mathrm{~cm}$. Cow milking is carried out in a milking parlor with 40 spots. A rotary milking unit and Westfalia milking machines are installed for cow milking.

Cow watering is carried out from group drinking bowls. Two group drinking bowls are installed in one section so that the cows do not disturb each other. In the summer heat peri- 
od, cows spend more time at group drinking bowls; first heifers, weak, sick cows are afraid and cannot come up to meet their water needs.

The height of the drinkers is $40 \mathrm{~cm}$, which is sufficient. Animals freely approach the drinking bowls and drink water in large gulps without squeezing the neck and throat, that is, they do not experience discomfort when drinking water.

Milk is counted by group and individually from each cow, which is recorded in the computer database. Milk is cooled in cooling tanks at a temperature of $4-6{ }^{0} \mathrm{C}$. At this temperature, the reproduction of bacteria stops. Insemination of cows is carried out in special machines in a rectocervical way. The farm has introduced $100 \%$ synchronization of oestrum in cows. Manure removal in the premises with loose cubicle cow keeping technology is carried out using a delta-scraper conveyor. The removal of manure from under the cows in the sections is carried out automatically every 2 hours, i.e. 12 times a day.

Indoor lighting is provided with the help of skates, side windows; in addition, there are special windows at the end of the building, additional artificial lighting is provided in cloudy and winter times. The regulation of the microclimate parameters in the premises is carried out with the help of Italian-made fans; in addition, there are supply and exhaust fans from the end of the building. In addition, a sleeve is adapted for forced ventilation inside the room. In the middle of the room, there are five Italian-made fans that run continuously.

The farm is disinfected and whitewashed once in every year. In the farm, a large role is assigned to the work of cattlemen, who influence the receipt of high results in cattle breeding. The cattlemen work in three shifts: 1 shift works from 7.00 to $15.00 ; 2$ nd shift works from 15.00 to 23.00 hours; the third shift works from 23.00 to 7.00 in the morning. Thus, one work shift is 8 hours.

The duties of the cattlemen include: pushing feed on the manger at least 5-6 times per shift, distributing concentrates once per shift, distributing mineral additive (chalk, fodder salt) once per shift, removing manure after 2 hours.

\section{Results and discussion}

During the study, the timing of the cows' milking was carried out on the rotary milking unit with loose-box technology of cow keeping and milking in the milking parlor.

Cow milking at the rotary milking unit includes the following operations and is carried out in the following sequence:

- driving cows from the section to the pre-milking area;

- waiting for the cows to be milked at the pre-milking area;

- entry of cows into the milking parlor for milking;

- treatment of dugs with a disinfectant (foam);

- milking the first streams of milk;

- connection of the milking machine;

- milking process;

- switching off the milking machine;

- dug processing after milking;

- exit of cows from the milking parlor;

- driving cows back to the section.

Cow milking by production groups is carried out in the following sequence:

Group 1 - production group - cows two months before launch;

Group 2 - milk yield increase - cows from the sixth day after calving and up to two months;

Group 3 - the main group - inseminated cows not tested for pregnancy (fresh cows);

Group 4 - mastitic cows. 
Also, the timing and analysis of each technological operation was carried out separately for a specific production group of cows. First operation (time spent on driving cows from section to pre-milking area). The research results showed that for the production group it took 3 minutes 36 seconds to drive cows from the sections to the pre-milking area; for the main group, this indicator was 3.20 minutes; for the milk yield increase group - 3.15 minutes; in the group of mastitic cows - 3.36 minutes (table 1). Thus, it takes an average of 3.15 to 3.36 minutes to drive cows from the sections to the pre-milking area.

Second operation (waiting time for milking at the pre-milking area). The research results showed that for the production group of cows, it took 5 minutes 20 seconds to wait for milking at the pre-milking site of the first batch of the first 40 cows; the second batch (40 heads) took 11 minutes 41 seconds; third batch (40 heads) - $23.22 \mathrm{~min}$. For the main group, the waiting time for the first batch of the first 40 heads was 5 minutes 15 seconds; the second batch (40 heads) took 11 minutes 52 seconds; third batch (40 heads) - 23.26 minutes.

In the milk yield increase group, the waiting time for the first batch of the first 40 heads was 5 minutes 35 seconds; the second batch (40 heads) took 11 minutes and 50 seconds; third batch (40 heads) - $23.10 \mathrm{~min}$. In the group of mastitic cows, the waiting time for milking was 5.20 minutes. Thus, on average, it took from 5 minutes 15 seconds to 5 minutes 35 seconds to wait for the first batch of the first 40 cows to be milked at the pre-milking area; the second batch ( 40 heads) took from 11 minutes 41 seconds to 11 minutes 52 seconds; the third batch (40 heads) - from 23.10 minutes to 23.26 minutes.

The third operation (the time for the cows to enter the milking parlor). The research results showed that for the production group, the time of cow entry into the milking parlor for milking from the first cow to the last 40th cow amounted to 11.41 minutes; in the main group - $11.52 \mathrm{~min}$; for the milk yield increase group - $11.50 \mathrm{~min}$; in the group of mastitic cows - 5-6 minutes (table 1).

Consequently, on average, the time of cow entry into the milking parlor for milking from the first cow to the last 40th cow took from 11.41 minutes to 11.52 minutes.

The fourth operation (time for dug foam treatment (disinfection). The research results showed that in the production group of cows, $3.70 \pm 0.27$ seconds were spent on dug foam treatment (disinfection); in the main group - $3.8 \pm 0.84 \mathrm{~s}$; in the milk yield increase cow group $-4.0 \pm 0.63 \mathrm{~s}$, in the mastitic cow group $-4.10 \pm 0.55 \mathrm{~s}$ (Table 1$)$.

Foam (for 20 liters of water: $800 \mathrm{~g}$ of liquid soap $+800 \mathrm{~g}$ of glycerin $+400 \mathrm{~g}$ of hydrogen peroxide). Thus, on average, dug foam treatment (disinfection) took from 3.70 to 4.10 seconds. Fifth operation (time for the first milk streams to be milked). The research results showed that in the production group of cows it took $20.8 \pm 1.64$ seconds to milk the first streams; in the main group - $17.44 \pm 2.25 \mathrm{~s}$; in the milk yield increase group - $10.17 \pm 2.64$ $\mathrm{s}$; in the group of mastitic cows - 10.8 seconds (table 1 ). Thus, on average, it took from 10.17 to 20.80 seconds to milk the first streams. Sixth operation (milking machine connection time). The research results showed that in the production group of cows, $9.4 \pm 1.67$ seconds were spent on connecting the milking machine; for the main group - 7.2 $\pm 0.45 \mathrm{~s}$; in the milk yield increase group - $10.67 \pm 6.86 \mathrm{~s}$; in the group of mastitic cows $-10.6 \pm 7.57$ $\mathrm{s}$ (table 1). Thus, on average, it took from 7.20 to 10.67 seconds to connect the milking machine. Seventh operation (milking time). The research results showed that in the production group of cows, it took $4.29 \pm 1.08$ minutes to milk the cows; in the main group $-5.15 \pm$ $2.56 \mathrm{~min}$; in the milk yield increase group - $5.00 \pm 2.61 \mathrm{~min}$; in the group of mastitic cows $5.28 \pm 1.73 \mathrm{~min}$ (table 1). Thus, on average, cow milking took from 4.29 to 5.28 minutes.

Eighth operation (switching off the milking machine). After milking the cows, the milking machines switch off automatically.

Ninth operation (dug treatment time after milking). The research results showed that in the production group of cows, $3.72 \pm 0.61$ seconds were spent on dug treatment after milking; for the main group - $3.00 \pm 0.50 \mathrm{~s}$; in the milk yield increase group - $4.17 \pm 1.17 \mathrm{~min}$; 
in the group of mastitic cows $-3.64 \pm 1.53 \mathrm{~s}$ (table 1). Thus, on average, dug treatment after milking cows took from 3.00 to 4.17 seconds.

Table 1. Timing of cows' milking on the rotary milking unit in the milking parlor.

\begin{tabular}{|c|c|c|c|c|c|c|c|c|c|}
\hline \multirow{3}{*}{$\begin{array}{l}\text { Group } \\
\text { of cows }\end{array}$} & \multicolumn{9}{|c|}{ Operation and sequence of operations } \\
\hline & 1 & 2 & 3 & 4 & 5 & 6 & 7 & 8 & 9 \\
\hline & 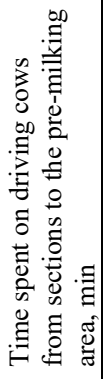 & 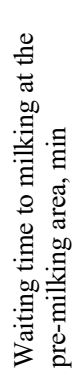 & 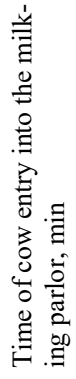 & 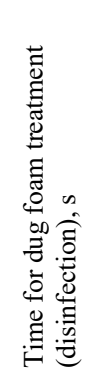 & 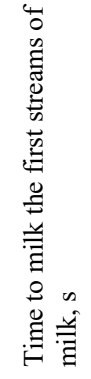 & 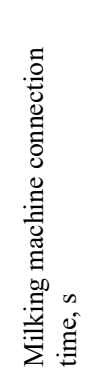 & 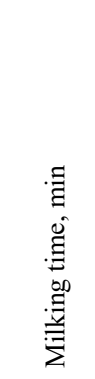 & 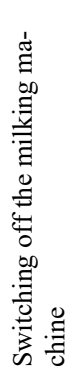 & 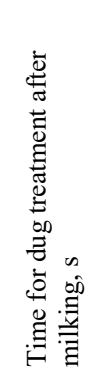 \\
\hline $\begin{array}{l}\text { Production } \\
\text { group of cows } \\
2 \text { months be- } \\
\text { fore calving }\end{array}$ & 3.36 & $\mathrm{X}$ & $\mathrm{X}$ & $\begin{array}{l}3.70 \\
\pm 0.27\end{array}$ & $\begin{array}{c}20.8 \\
\pm 1.64\end{array}$ & $\begin{array}{c}9.4 \\
\pm 1.67\end{array}$ & $\begin{array}{c}4.2 \\
9 \pm 1.08\end{array}$ & auto & $\begin{array}{c}3.72 \\
\pm 0.61\end{array}$ \\
\hline $\begin{array}{l}\text { The main } \\
\text { group - fresh } \\
\text { inseminated } \\
\text { cows not tested } \\
\text { for pregnancy }\end{array}$ & 3.20 & $\mathrm{X}$ & $\mathrm{X}$ & $\begin{array}{c}3.8 \\
\pm 0.84\end{array}$ & $\begin{array}{l}17.44 \\
\pm 2.25\end{array}$ & $\begin{array}{c}7.2 \\
\pm 0.45\end{array}$ & $\begin{array}{c}5.15 \\
\pm 2.56\end{array}$ & auto & $\begin{array}{l}3.00 \\
\pm 0.50\end{array}$ \\
\hline $\begin{array}{l}\text { Milk yield } \\
\text { increase cow } \\
\text { group }\end{array}$ & 3.15 & $\mathrm{X}$ & $\mathrm{X}$ & $\begin{array}{c}4.0 \\
\pm 0.63\end{array}$ & $\begin{array}{l}10.17 \\
\pm 2.64\end{array}$ & $\begin{array}{l}10.67 \\
\pm 6.86\end{array}$ & $\begin{array}{c}5.00 \\
\pm 2.61\end{array}$ & auto & $\begin{array}{l}4.17 \\
\pm 1.17\end{array}$ \\
\hline $\begin{array}{c}\text { Mastitic group } \\
\text { of cows }\end{array}$ & 3.22 & $\mathrm{X}$ & $\mathrm{X}$ & $\begin{array}{c}4.1 \\
\pm 0.55 \\
\end{array}$ & $\begin{array}{c}10.8 \\
\pm 6.38 \\
\end{array}$ & $\begin{array}{c}10.6 \\
\pm 7.57 \\
\end{array}$ & $\begin{array}{c}5.28 \\
\pm 1.73 \\
\end{array}$ & auto & $\begin{array}{c}3.64 \\
\pm 1.53 \\
\end{array}$ \\
\hline
\end{tabular}

continuation of the table 1

\begin{tabular}{|c|c|c|c|c|c|c|c|}
\hline \multirow{3}{*}{$\begin{array}{l}\text { Group } \\
\text { of cows }\end{array}$} & \multicolumn{7}{|c|}{ Operation and sequence of operations } \\
\hline & 10 & 11 & 12 & 13 & 14 & 15 & 16 \\
\hline & 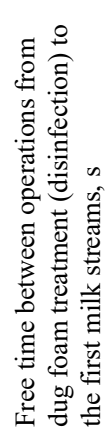 & 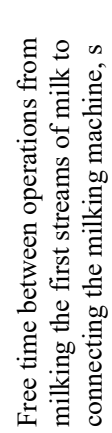 & 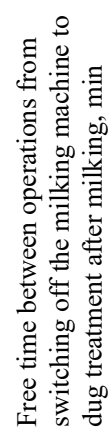 & 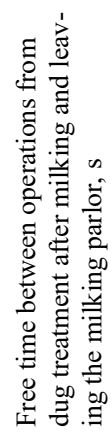 & 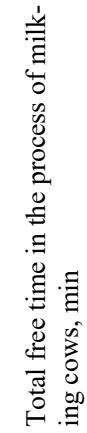 & 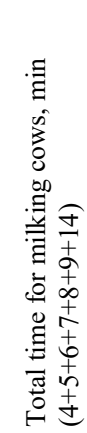 & 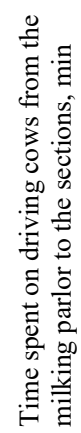 \\
\hline $\begin{array}{c}\text { Production } \\
\text { group of cows } \\
2 \text { months } \\
\text { before calv- } \\
\text { ing }\end{array}$ & $\begin{array}{c}46.4 \\
\pm 8.62\end{array}$ & $\begin{array}{c}33.6 \\
\pm 10.69\end{array}$ & $\begin{array}{c}3.30 \\
\pm 0.61\end{array}$ & $\begin{array}{c}38.6 \\
\pm 19.33\end{array}$ & $\begin{array}{c}5.27 \\
\pm 0.96\end{array}$ & $\begin{array}{l}10.37 \\
\pm 1.90\end{array}$ & 3.40 \\
\hline $\begin{array}{l}\text { The main } \\
\text { group - fresh } \\
\text { inseminated } \\
\text { cows not } \\
\text { tested for } \\
\text { pregnancy }\end{array}$ & $\begin{array}{c}52.4 \\
\pm 4.56\end{array}$ & $\begin{array}{c}36.8 \\
\pm 9.73\end{array}$ & $\begin{array}{c}3.43 \\
\pm 2.49\end{array}$ & $\begin{array}{c}42.8 \\
\pm 7.95\end{array}$ & $\begin{array}{c}5.53 \\
\pm 2.97\end{array}$ & $\begin{array}{l}13.69 \\
\pm 2.74\end{array}$ & 3.30 \\
\hline Milk yield & 51.8 & 33.0 & 3.83 & 36.6 & 6.26 & 12.82 & 3.25 \\
\hline
\end{tabular}




\begin{tabular}{|c|c|c|c|c|c|c|c|}
\hline $\begin{array}{c}\text { increase cow } \\
\text { group }\end{array}$ & \pm 3.77 & \pm 8.09 & \pm 0.65 & \pm 14.15 & \pm 3.93 & \pm 7.24 & \\
\hline $\begin{array}{c}\text { Mastitic } \\
\text { group of cows }\end{array}$ & $\begin{array}{c}50.2 \\
\pm 7.92\end{array}$ & $\begin{array}{c}48.4 \\
\pm 9.29\end{array}$ & $\begin{array}{c}3.93 \\
\pm 1.23\end{array}$ & $\begin{array}{c}34.4 \\
\pm 15.63\end{array}$ & $\begin{array}{c}30.6 \\
\pm 8.26\end{array}$ & $\begin{array}{c}6.21 \\
\pm 1.51\end{array}$ & 3.28 \\
\hline
\end{tabular}

The tenth - fourteenth operations (free time in the process of milking cows). The research results showed that in the process of cow milking in the production group, 5.27 minutes of free time were spent; for the main group, this indicator was 5.53 minutes; for a the milk yield increase group - 6.26 minutes; in the mastitic group - $6.21 \mathrm{~min}$ (table 1).

Thus, average free time spent in the process of milking cows was from 5.27 to 6.21 minutes. Fifteenth operation (time spent on driving cows from the milking parlor to the sections). The research results showed that for the production group it took 3 minutes 40 seconds to drive cows from the milking parlor to the section; for the main group, this indicator was 3.30 minutes; for the milk yield increase group - 3.20 minutes; the mastitic group - 3.28 minutes (table 1). Thus, it took an average of 3.25 to 3.40 minutes to drive cows from the pre-milking area to the sections. In total, the milking process took 26 minutes from entering to leaving the milking parlor.

\section{Conclusions}

Based on the research results, we can recommend the following to the farm:

1. Due to the increased incidence of outbreaks of infectious diseases, disinfect and whitewash the premises at least twice a year.

2. Use sawdust, chopped straw or a mixture of two components as bedding material in cow rest cubicles.

3. For the convenience of cow maintenance, milking and in to reduce the waiting time for milking on the pre-milking area, place cows in sections of no more than 50 heads.

4. Add one more milking machine operator, as the time gap from switching off the milking machine to dug treatment after milking is too large.

\section{References}

1. P.I. Zelenkov, A.I. Baranikov, A.P. Zelenkov, Cattle breeding, 571 (2005; 2006)

2. S.N. Izhboldina, Modern technologies for mechanized cow milking, 48 (2007)

3. G.Y. Berezkina, A.A. Korepanova, S.L. Vorobyova, E.M. Kislyakova, M.I. Vasilieva, Advances in animal and veterinary sciences, 8(Sp.I.3), 23-26 (2020)

4. M.R. Kudrin, G.Y. Berezkina, A.L. Shklyaev, L.A. Shuvalova, I.A. Deryushev, IOP Conference Series: Earth and Environmental Science, 7, 072034, 315 (2019)

5. M.R. Kudrin, S.N. Izhboldina, K.L. Shklyaev, V.A. Nikolaev, N.V. Selezneva, IOP Conference Series: Earth and Environmental Science 7, 072028, 315 (2019)

6. O.A. Krasnova, N.P. Kazantseva, M.R. Kudrin, E.V. Khardina, M.I. Vasilieva, M.G. Pushkaryov, N.A. Sannikova, International transaction journal of engineering, management and applied sciences and technologies, (11)14, 11A14G (2020)

7. N.M. Kostomakhin, Animal husbandry: Textbook, 432 (2007)

8. G.V. Rodionov, N.M. Kostomakhin, L.P. Tabakova, Cattle breeding: Textbook, 488 (2017)

9. N.N. Zezin, V.F. Gridin, S.L. Gridina, A.S. Nikiforov, Recommendations for keeping and operation of cattle in a complex with loose technology, 68 (2015) 
10. A.I. Lyubimov, S.L. Vorobyova, A.S. Chukavin, Scientific notes of the Kazan State Academy of Veterinary Medicine n. a. N. E. Bauman 232(4), 99-105 (2017)

11. E. Klimova, M.R. Kudrin, T. Krylova, E. Maksimova, E.A. Mikheeva, Advances in animal and veterinary sciences 8(Sp.I.3), 56-62 (2020)

12. E.M. Kislyakova, S.L. Vorobyova, S.I. Kokonov, IOP Conference Series: Earth and Environmental Science, 6 (062020), 315 (2019)

13. M.I. Vasilieva, Innovative technologies for the implementation of the program of scientific and technological development of agriculture: materials of the International scientific and practical. conf., 2, 16-18 (2018)

14. M.R. Kudrin, A.A. Astrakhantsev, O.A. Krasnova, E.S. Klimova, A.V. Kostin, A.B. Spiridonov, International Transaction Journal of Engineering, Management and Applied Sciences and Technologies, 11(10), 11A10U (2020) 